\title{
Micronuclei as A Biomarker in Monitoring Genetic Damage in Down Syndrome
}

\author{
Prasanna MD¹, Ayesha Sameera², Kranti Kiran Reddy Ealla³,
} Surekha Reddy Velidandla ${ }^{4}$, Sangameshwar Manikya ${ }^{5}$

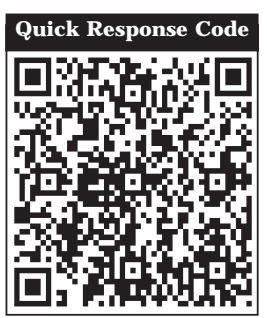

doi: $10.5866 / 2015.7 .10032$

${ }^{1}$ Professor and Head

${ }^{2}$ Post graduate

${ }^{3 \& 4}$ Reader

${ }^{5}$ Senior Lecturer

Department of Oral Pathology and Microbiology, MNR Dental College and Hospital, Sangareddy,

Telangana State

\section{Article Info:}

Received: J anuary 10, 2015

Review Completed: February 9, 2015

Accepted: March 11, 2015

Available Online: April, 2015 (www.nacd.in)

(c) NAD, 2015 - All rights reserved

\section{Email for correspondence:}

kaalmahesh@gmail.com

\section{ABSTRACT:}

Background: Down syndrome (DS) is a most common cause of mental retardation in humans. Monitoring genetic damage in DS individuals helps in evaluating genetic damage. Micronucleus assay is potentially an excellent tool to serve as a biomarker which detects chromosomal loss or malfunction.

Aim of the study: The objective of the study is to evaluate micronuclei (MN) frequency in exfoliated buccal cells in DS individuals.

Materials and Methods: The study subjects consisted of clinically diagnosed cases of Down syndrome. Healthy subjects without any medical conditions formed the control group. The cyto-smears were stained with Papanicolaou stain.

Results and Conclusion: The presence of increased number of micronuclei in Down syndrome $(\mathrm{P}<0.05)$ patients may be useful in identifying individuals with increase risk of mental retardation.

Key words: Down syndrome; Micronudeus; Genetic damage

\section{INTRODUCTION:}

Down syndrome (DS) is a most frequent cause of mental retardation in humans, with frequency of 1 in 800 live births. ${ }^{1}$ It is due to the inheritance of an extra copy of chromosome 21 as a result of chromosomal non-dysjunction during meiosis.

Although the chromosomal basis of DS have been known for 50 years, there is still a surprising lack of knowledge about the methods of monitoring genetic damage in DS individuals. Micronucleus assay is potentially an excellent tool to serve as a biomarker which detects chromosomal loss or malfunction of mitotic spindles caused by aneugenic mechanism. ${ }^{2}$ The objective of the study is to evaluate micronuclei (MN) frequency in exfoliated buccal cells in DS individuals.

\section{MATERIALS AND METHODS:}

The study sample comprised of 28 Down syndrome individuals and 28 healthy controls, matched according to the age and gender (Table 1).

\section{Indian Journal of Dental Advancements Journal homepage: www. nacd. in}


All the Down syndrome individuals or their guardians signed post-informed consent for the study.

\section{CELL COLLECTION, SLIDE PREPARATION AND SCORING:}

Smears were taken from clinically normal buccal mucosa of the patients using wooden spatula moistened in distilled water. The scrapings were then transferred to clean glass previously marked with patient's reference number, and spread thinly and uniformly over the slide. After air drying, they are fixed and stained with Papanicolaou (PAP) stain. Whol eslide is screened for counting $\mathrm{MN}$ at 400X and 1000X magnifications. Micronuclei (Figure 1) are counted using Tolbert et al criteria. ${ }^{3}$

\section{STATISTICAL ANALYSIS:}

Statistical analysis was carried out using Student $t$ test to compare the frequency of MN cells between DS and healthy controls, age groups and gender in DS. Values are expressed as means tstandard deviation. The level of significance is $5 \%$ $(P \leq 0.05)$.

\section{RESULTS:}

Micronucleus frequency was significantly higher in DS than controls (about 2 fold; $\mathrm{P} \leq 0.05$ ) and higher in maleDS compared to females DS (1.75 fold; $P \leq 0.05)$. Significant increase of $M N$ was observed in ol der DS age group compared to younger DS age group (1.5 fold; $\mathrm{P} \leq 0.05)$ (Graph 1 ).

\section{DISCUSSION:}

Micronuclei are small extra nuclear bodies formed by chromosome fragments or whole chromosome which did not reach spindle poles during mitosis and remained encapsulated at telophase in separate nucleus. They reflect structural or numerical chromosomal aberration. ${ }^{2}$

In the present study DS individuals showed 2 folds increase in $\mathrm{MN}$ frequency compared to that of controls. In agreement with the present results, Ferreira et al showed that MN frequency in buccal cells of DS individuals was about 3.25 fold higher than control group. ${ }^{4}$ Thomas et al also reported 7 folds higher $\mathrm{MN}$ frequency in DS individuals when compared with healthy controls and 2 folds higher when compared with older individuals. ${ }^{5}$ In contrast Scarfi et al observed lower incidence of $\mathrm{MN}$ in cytokinesis blocked lymphocytes in DS individuals than controls. ${ }^{6}$ However Maluf and Erdtmann found no significant difference between DS individuals and controls as evaluated by M N frequency in cytokinesis blocked Iymphocytes. ${ }^{7}$ The difference in the frequency of MN in buccal mucosa and lymphocytes could be explained by their metabolism. Simko et al demonstrated that different cell lines respond differently in terms of micronucleus induction and apoptosis in response to genotoxic insults. ${ }^{8}$

Several mechanisms are likely to be involved in formation of micronucleus in tissues of individuals affected by DS. These depend on the origin of micronucleus itselfi.e., from chromosomal breakage or from chromosomal mal-segregation.

Oxidative stress ensues when the normal balance between production of reactive oxygen species and antioxidant ability of the target cell is upset. This leads to cellular dysfunction resulting in elevated genomic instability such as MN formation and eventual cell death. In DS, Superoxide dismuthase 1 (SOD-1), an antioxidant enzyme encoded on chromosome 21(21q22.1) causes dismutation of superoxide anion into hydrogen peroxide and oxygen resulting in oxidative stress. ${ }^{9}$

Another plausible mechanism of $\mathrm{MN}$ formation is folicacid deficiency. Folate is an essential nutrient acting as methyl donor for conversion of deoxyuridine monophosphate (dUMP)to deoxythymidine monophosphate required for DNA synthesis and repair. Folate is also required for production of S-adenosylmethionine, the methylating agent required for maintenance of cystosine methylation patterns essential for gene expression regulation and for chromatin structure stability in critical areas such as centromeres. Under conditions of folate deficiency, Dump accumulates causing breaks in DNA strand as a result of base removal by glycosylases following uracil misincorporation into DNA in place of thymine leading to $\mathrm{MN}$ formation. And accumulation of homocystein also occurs due to folate deficiency. ${ }^{11}$ I mpairments in folate/ homocystein metabolism have been suggested as a risk factor for having 
Table 1: Age and gender of subjects studied

\begin{tabular}{lccccc} 
Group & \multicolumn{2}{c}{ Down's syndrome } & \multicolumn{2}{c}{ Control group } \\
Age & $<11$ years & $>11-<$ - 1 years & $<11$ years & $>11-<2$ years \\
\hline Male & 7 & 7 & 7 & 7 \\
\hline Female & 7 & 7 & 7 & 7 \\
\hline
\end{tabular}

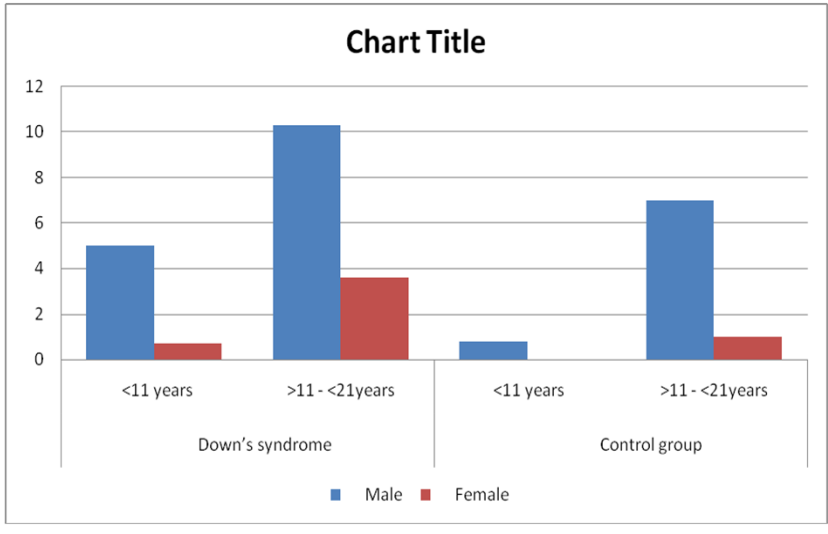

Graph 1: Frequency of micronuclei in buccal mucosal cells of Down syndrome and control individuals according to gender. Statistical significance according to the Student 't' test $(P \varangle 0.05)$.

infants with DS. It is based on the assumption that they could result in aberrant methylation of pericentromeric regions as well as of regions involved in chromosome recombination, thereby affecting chromosome 21segregation. ${ }^{12}$

In the present study, DS individuals aged $>11$ to $\leq 21$ years showed increased frequency of micronuclei than younger DS individuals $\leq 11$ years. In agreement, Ferreira et al also found positive correlation of $\mathrm{MN}$ with age. ${ }^{4} \mathrm{DS}$ is associated with lower DNA repair efficiency and accelerated decline in DNA repair capacity with age. ${ }^{13}$ Increasing age with DS is also associated with increase rates of depression, thyroid dysfunction and sensory impairment. ${ }^{14-16}$

DS individuals usually develop alzheimer's disease by fourth decade of life. It is because of constitutive trisomy 21 which results in over expression of genes mapping to chromosome 21 , in

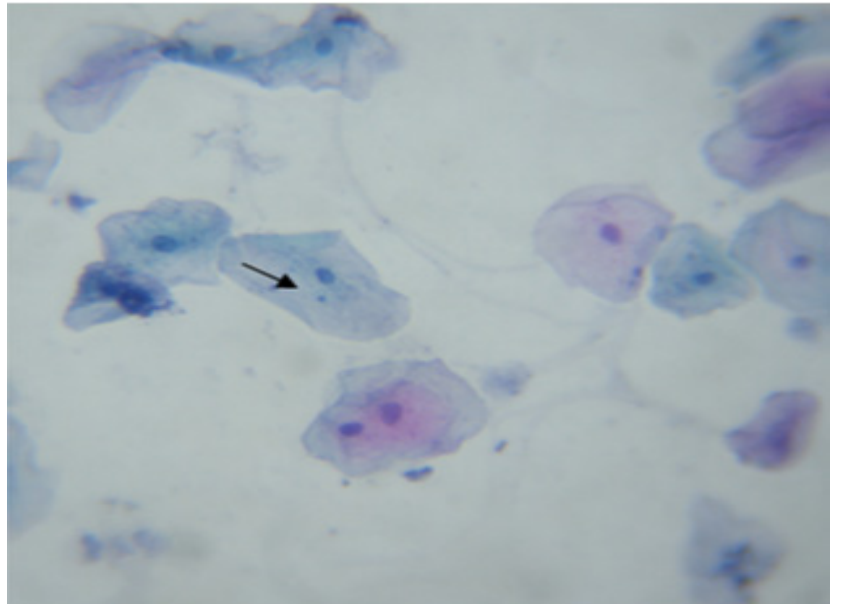

Figure 1: Photomicrograph showing the Miconuclei (100X)

particular that coding for amyloid precursor protein (APP). ${ }^{17}$ Alterations in frequency of $\mathrm{MN}$ have also been found in alzheimer's disease. ${ }^{18,}{ }^{19}$ So, determination of $\mathrm{MN}$ frequency might be applied to detect alzheimer's disease risk. Further insight is necessary to better understand the relation.

DS individuals have increased risk of leukaemia, retinoblastoma, lymphomas and germ cell tumors. ${ }^{20} \mathrm{MN}$ frequency has already been suggested for identifying individuals with high risk for cancer ${ }^{21}$ So, determination of MN frequency can probably also be applied for identifying DS individuals with high risk cancer.

Further studies should be conducted for better understanding the non-dysjunction process. The ultimate goal should be development of preventive treatment strategies. This can only be devel oped on the basis of clear understanding of pathological process involved. 


\section{REFERENCES:}

1. Migliore L, Boni G, Bernardini R, Trippi F, Colognato R, Fontana I, et al. Susceptibility to chromosome mal segregation in lymphocytes of women who had a Down syndrome child in young age. Neurobiol Ageing 2006; 27:710-716.

2. Holland N, Bolognesi C, Kirsch Volders M, Bonassi S Zeiger $\mathrm{E}, \mathrm{K}$ nasmueller $\mathrm{S}$, et al. The micronucleus assay in human buccal cells as a tool for biomonitoring DNA damage: the HUMN project perspective on current status and knowledge gaps. Mutat Res 2008; 659:93-108.

3. Tolbert PE, Shy CM, Allen J W. Micronuclei and other nuclear anomalies in buccal smears: methods development. Mutat Res 1992; 271:69-77.

4. Ferreira FLS, Pra D, Martino Roth MG, Garcias GL. Buccal micronucleus frequency is associated with age in Down syndrome. Genet Mol Res 2009; 8:1231-1237.

5. Thomas P, Fenech M. Chromosome 17 and 21 aneuploidy in buccal cells is increased with ageing and in Alzheimer's disease. Mutagenesis2008; 23:57-65.

6. Scarfi MR, Cossarizza A, Monti D, Bersani F, Zannotti M, Lioi MB, et al. Age-related increase of mitomycin C-induced micronuclei in lymphocytes from Down's syndrome subjects. Mutat Res 1990; 237:247-252.

7. Maluf SW, Erdtmann B .Genomic instability in Down syndrome and Fanconi anemia assessed by micronucleus analysis and single-cell gel electrophoresis. Cancer Genet Cytogenet 2001; 124:71-75.

8. Simko M, Kriehuber R, Weiss DG, Luben RA. Effects of 50 $\mathrm{HzEMF}$ exposure on micronucleus formation and apoptosis in transformed and nontransformed human cell lines. Bioelectromagnetics1998; 19:85-91.

9. Sulthana SM, Kumar SN, Sridhar MG, Bhat BB, Rao RK. Antioxidant enzyme activity in children with DS. Curr Paediatric Res 2012; 16:43-47.
10. Sulthana SM, Kumar SN, Sridhar MG, Bhat BB, Rao RK Oxidative stress in children with DS. Curr Paediatric Res 2012; 16:111-114

11. Fenech M Folate. DNA damage and the aging brain. Mech Ageing Dev 2010; 131:236-241

12. Coppede F. The complex relationship between folate/ homocysteine metabolism and risk of Down syndrome. Mutant Res 2009; 682:54-70.

13. Raji NS, Rao KS. Trisomy 21 and accelerated aging: DNArepair parameter in peripheral lymphocytes of DS patients. Mech Aging Dev1998; 85:1100-1101.

14. Burr DB, Loveland KA, Lewis KR. Depression and the onset of dementia in adults with mental retardation. Am J Ment Retard 1992; 96:502-511

15. Percy ME, Daltone AJ, Markovic D, Crapper McLachlan DR, Gera E, Hummel J T, et al. Autoimmune thyroiditis associated with mild "subclinical" hypothyroidism in adults with Down syndrome: A comparison of patients with and without manifestations of Alzheimer disease. Am J Ment Genet 1990; 36:148-154.

16. Ellis D. Sensory Impairments in mentally-handicapped people. London: Croom-Helm; 1986.

17. Petronis A. Alzheimer's disease and Down syndrome: from meiosis to dementia. Exp Neurol 1999; 58:403-413.

18. Thomas $P$, Fenech $M$. A review of genome mutation and Alzheimer's disease. Mutagenesis2007; 22:15-33.

19. Petrozzi L, Lucetti C, Scarpanto R, Gambaccini G, Trippi F, Bernardini S,et al. Cytogenetic alteration in lymphocytes in alzheimers and parkinsonism disease patients. Neurol Sci 2002; 23:97-98.

20. HasleH. Pattern of Malignant disorders in individuals with Down's syndrome. Lancet oncol 2001; 2:429-436

21. Bonassi S, Znaor A, Ceppi M, Lando C, Chang WP, Holland $\mathrm{N}$, et al. An increased micronucleus frequency in peripheral blood lymphocytes predicts the risk of cancer in humans. Carcinogenesis2007; 28:625-6231.

\section{Gain quick access to our journal online View our journal at www.nacd.in}

